\title{
COMPUTED TOMOGRAPHY-GUIDED BONE LESION BIOPSY, OUR EXPERIENCE IN 2018 AND 2019
}

\author{
ELVIRA KREŠIĆ ${ }^{1}$, ANA MARIJA ALDUK ${ }^{1}$, MAJA PRUTKI ${ }^{1,2}$, IVAN KARLAK ${ }^{3}$, \\ KAROLINA BOLANČA ČULO ${ }^{4}$ and MISLAV ČAVKA ${ }^{1,5}$ \\ ${ }^{1}$ Department of Diagnostic and Interventional Radiology, University Hospital Center Zagreb, \\ Zagreb, Croatia; \\ ${ }^{2}$ Department of Radiology, School of Medicine, University of Zagreb, Zagreb, Croatia; \\ ${ }^{3}$ Specialty Hospital Arithera, Zagreb, Croatia; \\ ${ }^{4}$ Division of Diagnostic and Interventional Radiology, Department of Oncological Radiology, \\ University Hospital for Tumors, Sestre milosrdnice University Hospital Center, Zagreb, Croatia; \\ ${ }^{5}$ Department of Social Medicine and Organization of Healthcare School of Medicine, \\ University of Zagreb, Zagreb, Croatia
}

\begin{abstract}
Summary
To present our results from 2018 and 2019 and to present the clinical data of the accuracy and clinical usefulness of computed tomography (CT)-guided biopsy for diagnosing suspicious bone lesion. The retrospective study included 98 consecutive patients who underwent CT-guided bone lesion biopsy from January 2018 to December 2019. The localization of the bone lesions, the adequacy of the sample for histopathological analysis, histopathological results, and the procedure's complications were analyzed. The specimens collected from 76 patients/lesions (77.6\%) were considered appropriate for diagnosis. Histological analysis of bone samples showed $52(68.4 \%)$ metastatic lesions. The most common primary tumor origins were breast carcinoma $28(53.8 \%)$ and lung carcinoma six (11.5\%). In three patients (4\%), the infection was confirmed. No tumor cells were found in $17(22.4 \%)$ patients. There were no post-procedural complications. CT-guided bone lesion biopsy is a safe and effective method for diagnosing suspicious bone lesions that has a great effect in clinical practice without any significant complications.
\end{abstract}

KEYWORDS: interventional radiology, metastasis, bone neoplasms, image-guided biopsy

\section{INTRODUCTION}

A CT-guided percutaneous biopsy is a powerful tool in the evaluation of the bone lesions suspicious of malignancy. Bone metastases and suspicious primary bone tumors constitute frequent indications for CT-guided biopsy. The approach to a lesion as recurrence of a known malignant tumor without histopathological confirmation may

Corresponding Author: Mislav Čavka, Department of Diagnostic and Interventional Radiology, University Hospital Center Zagreb, Kišpatićeva 12, 10000 Zagreb, Croatia.

e-mail: mcavka@kbc-zagreb.hr lead to inappropriate treatment of benign disease or incorrect management of a second primary tumor different from the first one. In suspicious metastatic breast cancer cases, bone lesion biopsies are very valuable because of receptor conversion in metastatic breast cancer.

The CT-guided biopsy is a safe and accurate method to define the diagnosis of suspicious radiologically detected bone lesion (1 - 4). A successful bone biopsy is defined as a procedure that gets enough material for an appropriate histopathological analysis. The rate of successful percutaneous bone biopsies of the musculoskeletal lesion is 


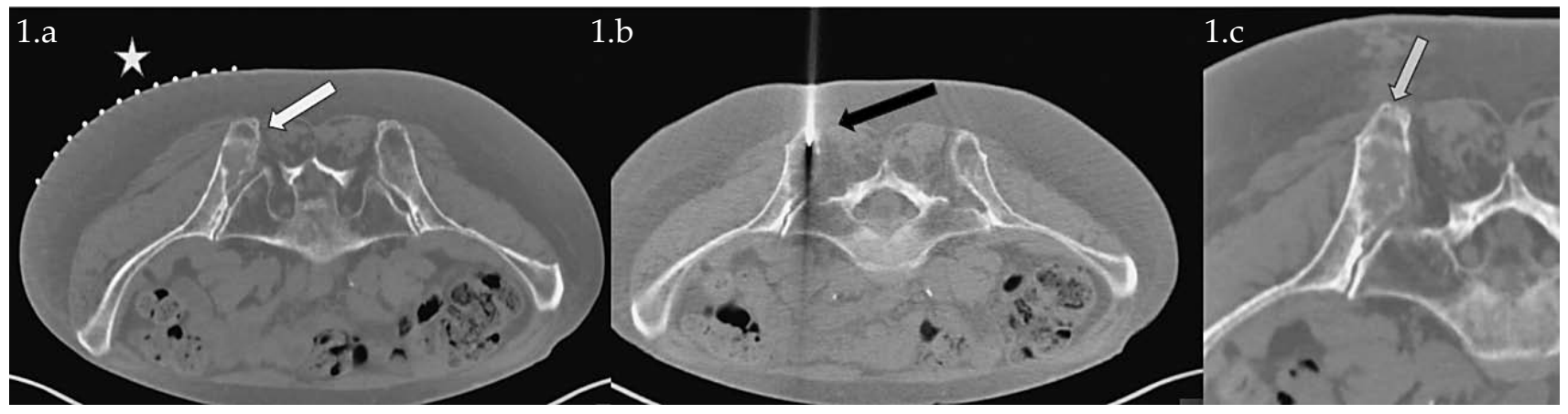

Figure 1. CT-guided percutaneous bone biopsy. A: Planning pelvic CT with the grid (star) demonstrates a lytic lesion in the left iliac bone (white arrow). B: Needle positioned within the target lesion (black arrow). C: Post-biopsy follow-up with no immediate complication and bone defect in the biopsy field (gray arrow).

$69-93 \%$ in the literature. (5-10). The rate of complications in CT-guided bone biopsies is very low $(1.1 \%)$, while in surgical (open) biopsies, it may be as high as $16 \%$ (11). This retrospective study aimed to determine the diagnostic definition and complications of CT-guided bone lesion biopsies.

\section{MATERIALS AND METHODS}

The retrospective study included 98 consecutive patients who underwent CT-guided bone lesion biopsy between January 2018 and December 2019 at the University Hospital Center Zagreb. Before the procedure, imaging data were reviewed in order to plan a safe and effective biopsy. Before the biopsy, the patient's laboratory results (such as platelet count and prothrombin time) were reviewed.

The patient positioning on the CT table for biopsy was based on the targeted bone lesion's location. The selected site was confirmed by $6.0 \mathrm{~mm}$ thick CT sections, and a single section of the lesion was selected. The lesion approach was determined to avoid passing through more than one anatomical compartment and neurovascular structures. The spatial localization of the lesion and the correlation with the grid was determined (Figure 1). $36(36.7 \%)$ patients were under deep sedation, and $62(63.3 \%)$ patients were under local anesthesia. The specimens were collected with 9, 11, and 13 gauge needles. From 1 to 4 core samples were collected for histological analysis depending on the macroscopic appearance of the specimens and lesion localization and size. Specimens were submitted in $10 \%$ formalin.
Localization of the bone lesion, the sample's adequacy for histopathological analysis, histopathological results, and the procedure's complications were analyzed.

\section{RESULTS}

In frequency order, involved bones were the following: $44(44.9 \%)$ iliac bone, $10(10.2 \%)$ vertebrae, sacrum $9(9.2 \%)$, sternum $8(8.2 \%)$, femur 8 $(8.2 \%)$, pubic bone $5(5.1 \%)$, tibia $4(4.1 \%)$, scapula $3(3.1 \%)$, rib $2(2 \%)$, acetabulum $2(2 \%)$, humerus 2 $(2 \%)$, medial cuneiform bone $1(1 \%)$. The specimens collected from 76 lesions $(77.6 \%)$ were considered appropriate for diagnosis. In $22(22.4 \%)$ lesions specimens were not adequate, of which 2 $(9.1 \%)$ were blood clots, one $(4.5 \%)$ was necrosis, 19 (86.4\%) were suboptimal sized samples for definitive pathohistological analysis. In 56 cases $(73.7 \%)$ metastatic lesions were confirmed and the primary tumor origins were the following: 28 $(53.8 \%)$ breast carcinoma, unknown origin $9(17.3 \%)$, lung carcinoma $6(11.5 \%)$, lower gastrointestinal tract carcinoma $1(2 \%)$, kidney carcinoma $1(2 \%)$, colon carcinoma $1(2 \%)$, pancreatic carcinoma 1 $(2 \%)$, stomach carcinoma $1(2 \%)$, prostatic carcinoma $1(2 \%)$, urothelial carcinoma $1(2 \%)$ and sarcoma $1(2 \%)$. In 1 case $(2 \%)$ metastatic bone lesion of neuroendocrine tumor was confirmed. In 3 patients $(4 \%)$ infection was confirmed. Plasmacytoma was confirmed in $3(4 \%)$ patients and nonHodgkin lymphoma in $1(1.3 \%)$ patient.

No tumor cells were found in 17 (22.4\%) patients. There were no post-procedural complications. 


\section{DISCUSSION}

CT-guided bone biopsy is a safe, accurate, and minimally invasive procedure for diagnosing radiologically detected suspicious bone lesions. It has a significant impact on the management of oncologic patients. In our study, the main indication for biopsy was the analysis of a suspicious metastatic lesion. Even in patients with a known primary tumor and suspicious bone lesion, whose chance of a diagnosis different from metastasis is low, the confirmation of the diagnosis is required because it can influence these patients' management and prognosis, especially for the patients with breast cancer.

This study's results have demonstrated that $77.6 \%$ of CT-guided bone lesion biopsy specimens were sufficient for histopathological analysis, which is in concordance with the reported rate of successful percutaneous bone biopsies of musculoskeletal lesion ranging from 69 to $93 \%$ (5-10).

We propose several potential reasons for a failed CT-guided bone biopsies; a failure in performing a biopsy of the target lesion, failure in collecting material sufficient for analysis or presence of necrosis in the specimens, impossibility of making a definite diagnosis based on nonspecific histological characteristics, and lack of confidence in results, requiring a new collection of specimen. Avoiding areas of necrosis correlates with a better rate of successful biopsies.

The procedure's guidance with other imaging methods may also be useful, for example, selecting as a target those areas with more significant metabolic activity at positron emission tomography with computed tomography (PET/CT) images (12-13). Also, collecting a greater number of specimens when possible is recommended. The rate of complications observed in the present study was zero and compatible with data in the literature. The rate of complications in CT-guided bone biopsies is very low (1.1\%), while in surgical (open) biopsies, it may be as high as 16\% (1). Based on our data, we can conclude that CT-guided bone lesion biopsy is a safe and effective method used as a gold standard for sampling bone lesions suspicious for malignancy.

\section{CONCLUSION}

CT-guided bone lesion biopsy is a safe and effective method for diagnosing suspicious bone lesions that significantly affects clinical practice without any significant complication.

\section{REFERENCES}

1. Altuntas AO, Slavin J, Smith PJ, Schlict SM, Powell GJ, Ngan S, et al. Accuracy of computed tomography guided core needle biopsy of musculoskeletal tumours. ANZ J Surg. 2005;75:187-91.

2. Jelinek JS, Murphey MD, Welker JA, Henshaw RM, Kransdorf MJ, Shmookler BM, et al. diagnosis of primary bone tumors with image-guided percutaneous biopsy: experience with 110 tumors. Radiology. 2002; 223:731-737.

3. Leffler SG, Chew FS. CT-guided percutaneous biopsy of sclerotic bone lesions: diagnostic yield and accuracy. AJR. 1999;172:1389-92.

4. Ashford RU, McCarthy SW, Scolyer RA, Bonar SF, Karim RZ, Staley PD. Surgical biopsy with intraoperative frozen section. An accurate and cost-effective method for diagnosis of musculoskeletal sarcomas. J Bone Joint Surg Br. 2006;88:1207-11.

5. Datir A, Pechon P, Saifuddin A. Imaging-guided percutaneous biopsy of pathologic fractures: a retrospective analysis of 129 cases. AJR. 2009;193:504-8.

6. Harish S, Hughes RJ, Saifuddin A, Flangan AM. Image-guided percutaneous biopsy of intramedullary lytic bone lesions: utility of aspirated blood clots. Eur Radiol. 2006;16:2120-5.

7. Ng CS, Salisbury JR, Darby AJ, Gishen P. Radiologically guided bone biopsy: results of 502 biopsies. Cardiovasc Intervent Radiol. 1998;21:122-8.

8. Puri A, Shingade VU, Agarwal MG, Anchan C, Juvekar S, Desai S. CT-guided percutaneous core needle biopsy in deep seated musculoskeletal lesions: a prospective study of 128 cases. Skeletal Radiol. 2006;35: $138-43$.

9. Wu JS, Goldsmith JD, Horwich PJ, Shetti SK, Hochman MG. Bone and soft-tissue lesions: what factors affect diagnostic yield of image-guided coreneedle biopsy? Radiology. 2008;248:962-70.

10. Dupuy DE, Rosenberg AE, Punyaratabandhu T, Tan $\mathrm{MH}$, Mankin HJ. Accuracy of CT-guided needle biopsy of musculoskeletal neoplasms. AJR. 1998;171: 759-62.

11. Welker JA, Henshaw RM, Jelinek J, Shmookler BM, Malawer MM. The percutaneous needle biopsy is safe and recommended in the diagnosis of musculoskeletal masses. Cancer. 2000;89:2677-86.

12. Werner MK, Aschoff $P$, Reimold $M$, Pfannenenberg $C$. FDG-PET/CT-guided biopsy of bone metastases sets a new course in patient management after extensive imaging and multiple futile biopsies. Br J Radiol. 2011; 84:e65-e67.

13. Bitencourt AGV, Tyng CJ, Pinto PNV, Almeida MFA, Meyrellis LC, Pinheiro RP, et al. Percutaneous biopsy based on PET/CT findings in cancer patients: technique, indications, and results. Clin Nucl Med. 2012; 37:e95-e97. 


\section{Sažetak \\ BIOPSIJE KOŠTANIH LEZIJA POD KONTROLOM CT-A, NAŠA ISKUSTVA IZ 2018. I 2019. \\ E. Krešić, A. Marija Alduk, M. Prutki, I. Karlak, K. Bolanča Čulo i M. Čavka}

Cilj rada je predstaviti naše rezultate iz 2018. i 2019. i dodati saznanja kliničkim podatcima o točnosti i kliničkoj korisnosti biopsije vođene kompjuteriziranom tomografijom kod dijagnosticiranja suspektnih koštanih lezija. Retrospektivno istraživanje obuhvatilo je 98 uzastopnih bolesnika koji su podvrgnuti biopsiji koštanih lezija pod kontrolom CT-a od siječnja 2018. do prosinca 2019. Analizirani su lokalizacija koštanih lezija, adekvatnost uzorka za patohistološku analizu, patohistološki rezultati i komplikacije postupka. Uzorci prikupljeni od 76 pacijentata iz 76 lezija $(77,6 \%)$ smatrani su prikladnima za dijagnozu. Histološka analiza uzoraka kostiju pokazala je $52(68,4 \%)$ presadničke lezije. Najčešći izvor primarnog tumora bio je rak dojke $28(53,8 \%)$, a rak pluća $6(11,5 \%)$. U 3 bolesnika $(4 \%)$ potvrđena je infekcija. U $17(22,4 \%)$ bolesnika nisu pronađene tumorske stanice. Biopsija koštanih oštećenja pod kontrolom CT-a sigurna je i učinkovita metoda bez ozbiljnijih komplikacija.

KLJUČNE RIJEČI: intervencijska radiologija, presadnice, novotvorine kosti, biopsije pod kontrolom slikovnih metoda 